\title{
Parking Levy Management in Increasing Locally-generated Revenue of Solok City, West Sumatra Province
}

\author{
Ira Meiyenti ${ }^{1 *}$, Ruri Hestiti ${ }^{2}$, Adam Maklubi $^{3}$, Ika Agustina ${ }^{4}$, Asep Hendra ${ }^{5}$ \\ \{irameiyenti@gmail.com ${ }^{1}$, hestitir@gmail.com², adammaklubi96@yahoo.com ${ }^{3}$, \\ ikaagustina1875@gmail.com ${ }^{4}$,hendraasep234@yahoo.com ${ }^{5}$ \}
}

\begin{abstract}
Institute of Governance of Home Affairs West Sumatra Campus, Jl. Raya Bukittinggi-Payakumbuh Km. 14¹, Balai Jaya District Office Rokan Hilir Regency, J1. Lintas Riau-Sumut Km.39², Institute of Governance of Home Affairs Jatinangor Campus, Jl. Ir. Soekarno, Km 20, Jatinangor, Sumedang ${ }^{345}$
\end{abstract}

\begin{abstract}
This study aims to analyze parking retribution Management in Increasing locally-generated revenue of Solok City, West Sumatra Province. Researchers used qualitative methods with a descriptive, inductive approach and data collection through interview techniques with 20 informants, as well as observation and documentation.

The results showed that the planning of the management of parking retribution is considered not following expectations. The organizational aspect has been formed even though the quantity of technical personnel is not proportional to the number of parking lots and the implementation of parking retribution management has not been done optimally. the supervision has been carried out both directly and indirectly for the implementation of parking service to the public. It can be concluded that the parking retribution management of Solok City has been done but has not significantly reached the target so that it has not been able to contribute in increasing the locally-generated revenue of Solok City. These are researcher's suggestions namely adding technical personnel in the parking section, repairing and adding facilities and infrastructure to support the process of collecting parking retribution, conducting socialization to the public, and updating the implementation of parking retribution collection.
\end{abstract}

Keywords: Management, Parking Retribution, Locally-generated revenue (PAD)

\section{Introduction}

Law Number 23 of 2014 concerning Regional Government explains that the implementation of regional government is carried out by giving the widest possible authority, accompanied by granting the rights and obligations to carry out autonomy so that it can regulate and manage its household[1]. Thus the region is given the authority to manage all assets including regional assets. Regions are also required to manage regional funding sources and carry out financial administration in the region itself[2].

Retribution becomes one of the financial sources of an area to increase locally-generated revenue[3]. Law No. 28/2009 concerning Regional Taxes and Levies explains that Retributions are divided into three categories namely public service levies, business service levies, and certain licensing levies[4]. One type of public service levy is parking fees. If managed well, it will provide benefits in supporting locally generated revenue[5] which can be used as superior revenue to encourage government activities and development for the public welfare[6] especially for cities that have a strategic geographical position such as Solok City. 
The geographical position of Solok City is in the heart of West Sumatra Province which is a crossing area if you want to go to Padang City, North Sumatra Province, and Jambi Province.

However, the provision of parking lots in Solok City is still relatively small and the land is still limited. Yet in terms of the economy, the provision of parking lots by the government is very profitable to increase revenue[7] and Retribution is a strategic opinion for the Solok City government[8] to charge administration government. This levy is considered crucial because of the large number of migrants who come, stop and stay in Solok City.

Parking Retribution is one of the results of regional autonomy regulation[9]. The management process of collecting parking levies in Solok City is adjusted to Regional Regulation (PERDA) of Solok City Number 3 of 2012 concerning Withdrawal of Regional Levies. The Regional Regulation (PERDA) explains that the Transportation Agency is responsible for managing the collection of parking levies. This becomes a reference for the Department of Transportation (DISHUB) together with the Solok City Government to set a target of parking levies every year. It is intended that the target and realization can be achieved. The following are the targets and realization of parking fees from 2016 - 2018 set by the Transportation Department (DISHUB) together with the Solok City Government.

Table 1. Realization of Parking Retribution Receipt for 2016 to 2018

\begin{tabular}{ccccc}
\hline No. & Year & Target (Rp) & Realization (Rp) & Percentage (\%) \\
\hline 1 & 2016 & $265,634,000$ & $155,150,000$ & $58.4 \%$ \\
\hline 2 & 2017 & $280,560,000$ & $193,677,000$ & $69.03 \%$ \\
\hline 3 & 2018 & $663,966,000$ & $240,033,000$ & $36.1 \%$ \\
\hline \multicolumn{5}{c}{ Source: Regional Finance Agency of Solok City, 2019}
\end{tabular}

Based on the table above, we can conclude that Parking Levies in Solok city is quite alarming, wherein the realization of 2016 to 2018 the targets have not yet been reached. In 2016 the target was set at $\operatorname{Rp} 265,634,000$ with the realization of the percentage reaching only $58.4 \%$. In 2017 the target was set at $\mathrm{Rp} \mathrm{280,560,000}$ and experienced an increase in revenue with a percentage of $69.03 \%$. Then in 2018 parking fees will decrease from the revenue target of Rp. 663,966,000 and the percentage of achievement were only able to reach $36.1 \%$.

From the data above, there is an increase and decrease in parking fees revenue of the set target, this affects locally-generated revenue (PAD) of Solok City. there are some constraints, especially the limited space and lack of land caused the availability of parking lots provided by the Solok City Government to be limited. Furthermore, lack of attention and government oversight of the management of the parking lot. The intended oversight function is the process of monitoring by the parking team[10] as well as the unclear boundaries of parking areas managed by the government resulting in illegal parking carried out by unscrupulous people.

Another problems related to the retribution realization that did not reach the target were low public participation[11] and not aware of the importance of paying parking fees. This is because the people of Solok City do not understand the obligation to pay parking fees for parking services and services that have been provided by the Solok City Government. This research is interesting to analyze because Solok as a strategic area should increase the potential for parking levy management maximally so that Solok local revenues will increase.

Indeed with this study, we hope that it will give contribute to the scientific analysis of the management of retribution collection so that it can have a significant impact on the increase of local revenue, Thus the benefits obtained are greater than the amount issued as explained in Sulistiyanto's research. Sulistiyanto[12] further explained that the efficient management of local taxes and levies would bring benefits greater than needed. 
Subsequent research was conducted by Suprihati et al.[13] explained that regional retribution did not have a significant effect on locally generated revenue. This is in line with research conducted by Usman[14], which provides the results of research conclusions that partially, local taxes have a significant positive effect on locally generated revenue. While research by Susanto and Sugianto[15] related to tax relations, The previous year's retribution and locally generated revenue to economic growth explained that there was a two-way relationship that occurred between retribution income and economic growth.

Research related to levies was also conducted by Sarjiyati et.al[16] who discussed the same aspect of parking fees, but more specific to parking retribution on the roadside. The results showed that the contribution of parking fees in a roadside to the increase in local revenues decreased due to the implementation of parking services in Ngawi is not under Regulation No. 23/2011 about parking fees at the side of the road. Thus the research conducted by Hasan and Suratman[17] explained that the contribution of parking fees to regional income is relatively insignificant.

Similar to previous studies, this study examines and analyzes related local retribution but on a different aspect, specifically analyzing parking levies. The difference between this study and the research of Sulistiyanto[12], Suprihati et al[13], Usman[14], Susanto and Sugianto[15], Sarjiyati et.al[16], and Hasan and Suratman[17] lies in the research object, locus and research methods. Thus the findings of this study will be different from the results of previous studies that have been previously described. Besides, the purpose of this study is to analyze the management of parking levies in increasing Solok City Regional Original Income, West Sumatra Province.

\section{Literature Review}

\subsection{Management}

GR Terry[18] defines management as "A process framework that involves guiding or directing a group of people towards organizational goals or tangible goals ". Management is an activity, its implementation is "managing" or "management", while the executor is called "manager" or "manager". Whereas Stoner and Freeman[19] explained that management is the process of planning, organizing, leadership, and controlling the efforts of organizational members and the use of all organizational resources to achieve the stated organizational goals.

a) In this study, researchers analyzed the management of parking retribution using theories related to management functions proposed by G.R Terry. Furthermore, G.R Terry[18] explained that there are 4 management functions abbreviated as POAC, namely: Planning ( Planning) which describe and formulate the activities needed to achieve the desired results by selecting and relating facts and making and using estimates or assumptions for the future.

b) Organizing ( Organizing) is determining, grouping, and organizing activities, placing employees, providing resources, sharing basic tasks and functions to achieve goals.

c) Implementation (Actuating) is to inspire and encourage all members of the organization to try hard and sincerely by planning to achieve organizational goals.

d) Supervision (Controlling) is the process of setting standards, implementing, evaluating implementation, and making improvements so that implementation can proceed according to plan according to standards. 
Previous research conducted by Sulistiyanto[12], Suprihati et al[13], Usman[14], Susanto and Sugianto[15], Sarjiyati et.al[16], and Hasan and Suratman[17] had different conclusions between one with others, so further research is needed to confirm and convince whether local taxes provide significant benefits in increasing local revenue.

\subsection{Parking Retribution}

Retribution in general is a payment to the state made by people who use state services[20]. Whereas regional Retribution by Siahaan[21] as payments for certain services or permits that are specifically provided and / or granted by local governments for the benefit of individuals or entities. Furthermore, parking Retribution which is one of the types of regional user fees in the general service levies group explained that the service provides special benefits for individuals/bodies or entities that are required to pay fees, in addition to serving public interests and benefits[22].

\section{Method}

This research is qualitative research with a descriptive method and an inductive approach. This is following the research objectives to analyze, describe, and understand the management of parking levies in increasing Locally - Generated Revenue of Solok City, West Sumatra Province. Qualitative research is methods for exploring and understanding the meaning of several individuals or groups of people ascribed to social or humanitarian problems[23]. The descriptive method with an inductive approach is a way to seek an understanding of specific images so that they reach a general conclusion[24].Data collection techniques used by researchers are observation, interviews, and documentation related to documents, regulations, and relevant reports from 2016 to 2018 , to the latest data that has existed in 2019. Informants in this study amounted to 20 informants consisting of the Head of DISHUB Solok City, the Secretary DISHUB Solok City, the Head of Road Transportation, the Head of Terminal and Parking Transportation, the Head of the Technical Implementation Unit (UPTD) of Parking, 5 people of the Collecting Officers and the Obligatory Retribution 10 people.

Data analysis using management function theory by G.R Terry with the operational scope of research can be seen in the table below.

Table 2. Concepts, Dimensions and Indicators

\begin{tabular}{|c|c|c|}
\hline Concept & Dimension & Indicator \\
\hline \multirow{4}{*}{$\begin{array}{l}\text { Management } \\
\text { Functions } \\
\text { (George R. } \\
\text { Terry, 1977) }\end{array}$} & $\begin{array}{l}\text { Planning } \\
\text { (planning ) }\end{array}$ & $\begin{array}{l}\text { a) Determination of tasks to achieve goals. } \\
\text { b) Establish a comprehensive plan regardi } \\
\text { implementation of activities. } \\
\text { c) Anticipating problems that might arise }\end{array}$ \\
\hline & $\begin{array}{l}\text { Organizing } \\
\text { (Organizing ) }\end{array}$ & $\begin{array}{l}\text { a) Division of work tasks. } \\
\text { b) Choosing and assigning individuals to the right job }\end{array}$ \\
\hline & $\begin{array}{l}\text { Implementation } \\
\text { (Actuating) }\end{array}$ & $\begin{array}{l}\text { a) The participation of all parties. } \\
\text { b) Establish communication effectively. } \\
\text { c) Meeting the needs of workers }\end{array}$ \\
\hline & $\begin{array}{l}\text { Supervision } \\
\text { ( controlling ) }\end{array}$ & $\begin{array}{l}\text { a) Assess the results with job standards . } \\
\text { b) Carry out a comparison of results with initial work. } \\
\text { c) Provide corrective actions }\end{array}$ \\
\hline
\end{tabular}

Source: GR Terry, 1997, processed by researchers, 2020 
The concepts, dimensions, and indicators above have been processed by researchers who refer to the Management Function theory proposed by George R. Terry [18] and several indicators that have been tested from the results of previous research which are used as a reference for researchers to obtain accurately and able to improve the results of previous research.

\section{Results And Discussion}

Analysis of the results of this study refers to the theoretical framework and scientific literature related. The theoretical framework used in this research is the theory of management functions proposed by GR Terry, 1997, which includes four dimensions, namely (1) Planning (planning ), (2) Organizing (Organizing) (3) Implementation (Actuating), and (4) Supervision ( controlling ).

\subsection{Planning ( planning )}

\section{a) Assignment of Tasks}

At the assignment stage, the Department of Transportation (DISHUB) of Solok City has done action, namely the division of tasks of each section and sub-section in this case the UPTD Terminal and Parking Area. In this section, the Head of the UPTD Terminal and Parking Area has taken action by dividing several employees to collect, deposit, and archive. This is done so that the collection system runs according to the standard operating procedures set by the Solok City Transportation Department.

b) Establish a comprehensive plan regarding the implementation of activities

The Department of Transportation (DISHUB) of Solok City has established a comprehensive plan based on the vision and mission that has been set. The Head of the Department of Transportation has prepared a plan related to parking which includes the transfer of the name of the new parking manager, the addition of parking points due to removal from the Market Service, and how many parking points are managed by officers from the Department of Transportation. This is done so that the specified parking targets can be achieved.

\section{c) Anticipating problems that will arise}

Anticipating problems that will arise as part of the planning that has been taken by the Department of Transportation (DISHUB) Solok city. This is done by following the vision and mission flow that has been made by the Solok City Transportation Department. Solok City Transportation Department has prepared anticipation, namely the determination of the location of parking areas, the completeness of parking facilities and infrastructure, and making commitments in anticipating problems that occur in the field when providing parking services and conducting socialization to the public.

\subsection{Organizing ( Organizing )}

\section{a) Division of Tasks}

The division of work tasks is one of the important tasks carried out by the Department of Transportation (DISHUB) of Solok City, which in this case is under the field of UPTD Terminal and Parking. To support the vision and mission, the division of tasks is carried out to 
each employee both civil servants and employees who are still honorary or contract statuses of the 21 parking areas to be managed.

\section{b) Choosing and assigning individuals to the right job}

Selecting and assigning individuals according to their expertise and abilities is one of the tasks that must be completed by the Department of Transportation (DISHUB) of the Solok city, because of the large number of employees from different educational and skills backgrounds. Understanding the character and way of socializing employees is the main reference because employees who will be polled are faced with managers who have different characters.

\subsection{Implementation ( Actuating )}

\section{a) Exploitation of the anticipation of all parties}

In this indicator, all parties related to the management process of collecting parking retribution must cooperate so that the targets as well as the vision and mission of the Transportation Agency (DISHUB) can be achieved. Policies taken by the Head of Road Transport Section include working with the road traffic section to describe congestion if there is illegal parking carried out by persons who eat the roadside, in collaboration with the Finance and Program Section because the results of the collection of parking fees will be submitted to the Treasurer of the Transportation Agency ( DISHUB) later be submitted to the Regional Finance Agency (BKD), as well as discussing and communicating with parking lot managers so that the process of collecting parking retribution for services that have been provided by the government can proceed as planned.

\section{b) Establish communication effectively}

The Department of Transportation (DISHUB) of Solok City holds a meeting every weekend to find out the constraints experienced by officers collecting parking retribution in the field. Furthermore, communicating and discussing parking service managers and users to find out the situation of parking in the field. This is done so that reciprocal communication is effectively established. Besides, the Head of the Department of Transportation (DISHUB) along with the Secretary of the Department of Transportation (DISHUB) and the Head of the Terminal and Parking UPTD also conduct multilevel communications regarding the collection of parking retribution so that the collection and deposit process to the Treasury of the Transportation Office (DISHUB) can be done transparently and directed.

c) Meeting the needs of parking fees collector employees

In maximizing the performance results of both civil servant and honorary employees, various efforts have been made which include giving freedom in participation/opinion, motivation, and direction to members and personnel in charge of the management of parking fees. This is done to spur the performance of employees[25] in carrying out their duties diligently and under their conscience to increase awareness of their respective duties and obligations. Also, special allowances are made for employees who do the collection because the process of carrying out the collection can run until the evening which is calculated as excess working hours.

\subsection{Supervision ( controlling )}

\section{a) Assess results with job standards}

The Transportation Agency (DISHUB) evaluates whether the collection process and service meet the set standards or not. The supervision process of the collection of parking fees is carried out by observing directly to the field to avoid irregularities committed by persons 
who can cause an unfavorable image of the collection and service of parking fees in the public.

\section{b) Carry out a comparison of results with initial work}

The Department of Transportation (DISHUB) made a comparison between the initial work and the final results as a reference whether the management process of collecting parking retribution worked as expected or not by comparing it with last month's income. However, parking receipts received by the Solok City Government are the same every year unless there are additional parking lots or changes to the parking tariff policy set by the Solok City Government.

\section{c) Provide corrective actions}

The supervision of parking retribution management has not been maximized. This can be seen from the presence of undisciplined parking attendants who often leave the assignment location. In the field implementation, there is still illegal parking and there are still people who are reluctant to make payments on parking fees that have been provided. So this will have an impact on the receipt of parking fees rarely reach the target. For corrective actions in the form of tiered reprimand, if the officer fails to carry out the process of collecting parking fees such as arrears by the manager, the target report to the Treasurer of Transportation (DISHUB) is not achieved, and some officers are not disciplined in the process of parking retribution management.

\section{Conclusions}

From the results of the discussion that has been described, it can be concluded that the management of parking retribution in the Solok City has been done but has not significantly reached the target so that it has not been able to contribute in increasing the Regional Original Revenues in the Solok City. This is consistent with the results of research conducted by Suprihati et al, Usman, Sarjiyati et.al., and Hasan and Suratman. However, parking fees still have a relationship with local revenue and if managed properly will get great benefits under the results of research Susanto and Sugianto and Sulistiyanto.

The planning of parking retribution management is not according to expectations. However, the organization of parking fee management has been formed, although there is still a shortage, namely the quantity of technical personnel that is not proportional to the number of parking lots. In terms of implementation of the management of parking fees has not been done to the maximum. Furthermore, in terms of supervision is an aspect that determines what has been done, the purpose is to evaluate work performance and if necessary apply corrective actions so that the work results are under the plans that have been set. Solok City Transportation Department conducts direct and indirect supervision of the implementation of parking service activities for the public.

Suggestions given to the results of this study related to the management of parking retribution are adding technical personnel in the field of parking, improving and adding facilities and infrastructure to support the process of collecting parking fees, socializing to the public, and making updates on the implementation of parking fee levies such as one-stop parking that can be included in regional regulations and further policymaking in the form of derivative regulations from regional regulations governing sanctions related to the management process both from the Transportation Agency and the parking management. 
Thus, it is expected that parking fee management can be carried out well so that it reaches the determined target and is expected to be able to make a significant contribution to increasing locally generated Revenues in the Solok City, West Sumatra province.

\section{Acknowledgments}

This research is limited to one case that occurred in Solok City, West Sumatra Province. The results of this study can be useful for stakeholders. Further research is needed on how to manage retribution so that they can contribute significantly to the increase in Local Revenue.

By giving thanks to Allah SWT, and researchers thank all those who have helped in the process of writing this scientific work. Acknowledgments also the author gave to the Solok City, West Sumatra Province as a locus of research that has provided support both in the form of data and information, so researchers can complete this scientific article.

\section{References}

[1] N. Nurlian, S. Rofingatun, and I. K. Wamafma, "Analisis Kontribusi dan Potensi Retribusi Daerah," J. Kaji. Ekon. Dan Keuang. Drh., vol. 3, no. 2, pp. 84-100, 2018, doi: 10.31957/keuda.v3i2.709.

[2] I. K. Raiana, "Efektivitas Pengelolaan Dana Retribusi Parkir Sebagai Sumber Pendapatan Asli Daerah Di Kota Denpasar," J. Ilm. Raad Kertha, vol. 1, no. 2, pp. 80-93, Agustus 2018.

[3] S. J. GOMIES and V. PATTIASINA, "Analisis Kontribusi Pajak Daerah dan Retribusi Daerah Terhadap Pendapatan Asli Daerah di Kabupaten Maluku Tenggara," J. Ilm. Aset, vol. 13, no. 2, pp. 175-184, Agustus 2011.

[4] A. D. Purnantoro and D. Lituhayu, "Evaluasi Kebijakan Pemungutan Retribusi Parkir Berlangganan Kota Mojokerto," J. Public Policy Manag. Rev., vol. 8, no. 2, pp. 625-634, Apr. 2019, doi: 10.14710/jppmr.v8i2.23716.

[5] S. J. E. Sopbaba, S. Rusmiwari, and W. T. Hardianto, "IMPLEMENTASI KEBIJAKAN RETRIBUSI PARKIR TERHADAP PENDAPATAN ASLI DAERAH (PAD)," JISIP J. Ilmu Sos. Dan Ilmu Polit., vol. 1, no. 2, pp. 16-25, 2012.

[6] N. Liana, "OPTIMIZATION OF INCREASED ORIGINAL INCOME REGISTERED TO TOURISM CITY BOGOR AND DISTRICT BOGOR,” J. Ilm. LIVING LAW, vol. 9, no. 2, Jan. 2018, doi: 10.30997/jill.v9i2.1036.

[7] S. I. Timisela, M. Asnawi, and Y. Hafizrianda, "Analisis Penerimaan Retribusi Parkir Tepi Jalan Umum di Kota Jayapura," J. Kaji. Ekon. Dan Keuang. Drh., vol. 2, no. 1, pp. 1-22, 2017.

[8] D. Hadiyatno, S. Susiswo, S. Patimah, H. Nainggolan, and R. Ernayani, "THE EFFECT OF LOCAL TAXES, REGIONAL RETRIBUTION, AND OTHER LEGAL DISTRICT OWN SOURCE REVENUES ON THE INCREASE OF DISTRICT OWN SOURCE REVENUE," Humanit. Soc. Sci. Rev., vol. 8, no. 1, pp. 426-431, Jan. 2020, doi: 10.18510/hssr.2020.8153.

[9] A. Munir and M. Hudi, "KEADILAN DALAM RETRIBUSI PARKIR BERLANGGANAN," Mimb. YUSTITIA J. Huk. Dan Hak Asasi Mns., vol. 2, no. 2, pp. 214-222, Desember 2018.

[10] R. Jerry, A. Subeki, and A. Hakiki, "EVALUASI ATAS PENERIMAAN PAJAK DAN RETRIBUSI PARKIR PADA DINAS PENDAPATAN DAERAH DAN DINAS PERHUBUngan KOTA PAlEMBANG," AKUNTABILITAS J. Penelit. DAN Pengemb. Akunt., vol. 7, no. 1, pp. 27-36, Jan. 2013, doi: 10.29259/ja.v7i1.8884.

[11] F. Simangunsong, "The Evaluation Study of the Determination of the Sub-District IMB Retribution Revenue in Bandung District," JEJAK J. Econ. Policy, vol. 8, no. 2, pp. 183-199, Sep. 2015, doi: http://dx.doi.org/10.15294/jejak.v8i2.6170. 
[12] A. Sulistiyanto, "Analisis Pajak Daerah Dan Retribusi Daerah Provinsi Jawa Tengah," Effic. Indones. J. Dev. Econ., vol. 1, no. 3, pp. 214-223, Dec. 2018, doi: 10.15294/efficient.v1i3.27875.

[13] S. Suprihati, L. Kristiyanti, and M. Hajir, "IMPROVING REGIONAL ORIGINAL INCOME WITH TAX RECEIPT, REGIONAL RETRIBUTION AND REGIONAL WEALTH MANAGEMENT RESULTS IN SOLO RAYA,” Int. J. Econ. Bus. Account. Res. IJEBAR, vol. 2, no. 3, Sep. 2018, doi: 10.29040/ijebar.v2i3.337.

[14] R. Usman, "PENGARUH PAJAK DAERAH DAN RETRIBUSI DAERAH TERHADAP PENDAPATAN ASLI DAERAH (PAD)," JAF- J. Account. Finance, vol. 1, no. 1, p. 87, Sep. 2017, doi: 10.25124/jaf.v1i01.902.

[15] W. Susanto, and C. Sugianto, "The Structure of Regional Original Revenue and Its Effect on Economic Growth,” J. Perenc. Pembang., vol. 3, no. 1, pp. 68-102, Apr. 2019.

[16] S. Sarjiyati, K. Yitawati, and Z. Arifin, "PARKING RETRIBUTION ON THE SIDE OF THE ROAD TOWARDS THE IMPROVEMENT OF LOCALLY-GENERATED REVENUE OF NGAWI REGENCY," Leg. Standing J. Ilmu Huk., vol. 2, no. 2, p. 104, Oct. 2018, doi: $10.24269 /$ ls.v2i2.1241.

[17] A. R. Hasan and Suratman, "An Analysis of the Implementation of Parking Management Policies in Increasing the Regional Income of Makassar City,” IOSR J. Humanit. Soc. Sci. IOSR-JHSS, vol. 13, no. 3, pp. 01-06.

[18] G. R. Terry, Principles of management, 7th ed. Homewood, Ill: R. D. Irwin, 1977.

[19] J. A. F. Stoner and R. E. Freeman, Management, 5th ed. Englewood Cliffs, N.J: Prentice Hall, 1992.

[20] J. R. Kaho, Prospek otonomi daerah di Negara Republik Indonesia, Cet. 1. Jakarta: Rajawali Pers, 1988.

[21] M. P. Siahaan, Pajak Daerah dan Retribusi Daerah. Jakarta: Rajawali Pers, 2016.

[22] A. R. Ramadhon, "PENETAPAN TARIF RETRIBUSI PARKIR PADA PUSAT HIBURAN BEACHWALK DI KABUPATEN BADUNG,” J. Kertha Negara, pp. 1-5, 2018.

[23] J. W. Creswell and J. D. Creswell, Research design: qualitative, quantitative, and mixed methods approaches, Fifth edition. Los Angeles: SAGE, 2018.

[24] M. Nasir, Metode penelitian. Jakarta: Ghalia Indonesia, 1998.

[25] H. Sastrawinata, "Pengaruh Kesadaran Diri, Pengaturan Diri, Motivasi, Empati, Dan Keterampilan Sosial Terhadap Kinerja Auditor Pada Kap Di Kota Palembang," Sos. J. Ilmu Adm., vol. 1, no. 2, pp. 1-19, 2011. 